\title{
The Great Mosque of Sumenep as Character Education Material in Art and Culture Lesson
}

\author{
M.A. Rohman \\ Universitas Negeri Surabaya \\ Surabaya, Indonesia
}

\begin{abstract}
Character education becomes the solution to decrease moral damages which increasingly rises nowadays. It is characterized by the number of brawl, corruption, promiscuity, and others. Character education can be applied in various subject areas, including art and culture lessons. It can be inserted through the interpretation of a cultural heritage. The Great Mosque of Sumenep for example, is one of the cultural heritages found in Sumenep district that has the uniqueness of cultural acculturation in the architecture which contained values. The purpose of this research is to explore and study the character values in the building of the Great Mosque of Sumenep so that it can be used as teaching materials or character education materials. This is qualitative research. The data obtained through observation and literature study. The results found that in the building of the Great Mosque of Sumenep contained religious values, honesty, tolerance, discipline, creativity, etc.
\end{abstract}

Keywords-mosque; character education; art and culture lesson

\section{INTRODUCTION}

The current Indonesian morality indicates the need of special attention. This moral decline can affect all aspects of life, regardless of age and profession. For example, in the case of the brawl in Jagakarsa in August 2017, started with mutual insults in social media resulting fights and quarrel. In addition, the corruption case that occurred in Jambi in September 2017, Head of Correctional Institution (Kalapas) Class II B Muaratebo, Tebo District reportedly arrested the prosecutor after being stated as a suspect case of alleged corruption. Then, there is also the case of a high school English teacher in North Jakarta initials TS (25) who sent chats and pornographic images to his students. A teacher who is supposed to be a role model for his students becomes a person who is not worthy to be figured out and imitated.

Learning and moral as well as characters building nowadays are very necessary. One of the best ways to fix morality is through education. Moral education can be embedded in every subject area, including art and culture lessons. This lesson can build students' moral education by studying culture. According to J.J. Hoenigman in Sulasman \& Gumilar (2013), the form of culture is divided into three forms, namely; ideas, activities, and artifacts. In this case, character education can be learned from artifacts or cultural heritage. In this case, we can explore everything such as values, art, morals, and so forth. Tylor in Tilaar (2002) argued that culture or civilization is a complex whole of knowledge, belief, art, morals, law, customs, and other abilities and habits that human beings acquire as members of society. By studying cultural relics, we can obtain information about the people of that era, such as art, morals, values and so on. One of the cultural heritage that stands upright and still functioned to this day is the Great Mosque of Sumenep. The mosque is located on Jl. Trunojoyo. It is one of the second oldest mosques in Sumenep regency established during the reign of Panembahan Somala in 1781 (18th century). This mosque has a unique in terms of architecture. There is a cultural acculturation in the form of building architecture and also there are many moral values or characters that can be excavated and studied.

This study aims to explore and study the character values in the Great Mosque of Sumenep so that it can be used as teaching materials in art and culture lessons. The goal is to instill character education on students through the interpretation of its building. In fact, it showed some character values such as religious values, honesty, tolerance, discipline, hardworking, creative, independent, democratic, curiosity, spirit of nationalism, love the homeland, friendly/ communicative, love peace, like to read, and responsibility. This research has two main benefits. First, it teaches character education to the students so that they become the next better generation on morality and dignity. Second, it makes the students more loving, appreciating, and preserving the culture.

\section{METHOD}

This is qualitative research. The researcher gained the data through observation and library research. This research was preceded by formulating the problems to be studied from the Great Mosque of Sumenep, then the researchers conducted a literature study to collect the necessary reference materials for 

research purposes. Then, the researcher continued to do observation. It is needed to analyze the object shape so that researchers can explore characters values presented in it.

\section{RESULTS AND DISCUSSION}

Based on the results of observation and literature study, the data obtained in which the character education values performed in the Great Mosque of Sumenep are as follows:

\section{A. Religious}

It is obedient attitudes and behaviors in implementing religious teachings they adhered, tolerant to the implementation of other religious worship, and live in harmony with others.

Religious values in the Great Mosque of Sumenep discovered from the shape of the gate and the main building of the mosque. The shape of the tajug roof in each stack has different symbols if it is associated with religion. Tajug stack one symbolizes the faith, tajug stack two symbolizes Islam and tajug the last stack symbolizes ikhsan. The roof shape of the mosque gate that conical upwards symbolizes divinity [1].

Mukarrom explained that there are 13 pillars contained within the building. They imply the pillars of prayer (intention, standing for the capable, takbiratul ikhram, reciting AlFatehah, ruku', i'tidal, sujud, sitting between two greetings, sitting on the final tashahud, read the prophet's salutations, greetings, and orderly). The five doors on the eastern part of the mosque are interpreted as a warning to perform the five-time prayer, while the two doors on the south and north sides are interpreted as the nature of apostles (shiddiq, amanah, tabligh, fathonah). Finally, ten windows are interpreted to the number of angels (malaikat) [1].

\section{B. Honest}

It is behavior based on an attempt to make himself/ herself a trustworthy person in words, actions, and work.

According to Mukarrom (2001), two doors on the south and north sides are interpreted as the nature of apostles (shiddiq, amanah, tabligh, fathonah) [1].

Based on the explanation, the two doors that define the Prophet's characters are shiddiq (true/honest), amanah (trustworthy), tabligh (convey), and fathonah (intelligent). Shiddiq has true and honest meaning. It means that all deeds were done and words that come out of his tongue are always true and honest. The meaning of the two doors indicates the importance of honesty that human being must have to do. Because in this day, honesty and truth is very rare and become an expensive character.

\section{Tolerance}

It is attitudes and actions that respect the different religions, tribes, ethnicities, and opinions. In more detail, it is attitudes and actions of appreciating others in diversity.

The existence of tolerance in this building is very clear. It is on various cultural elements which formed this building. The blending of the various cultures lies in the shape of gates and mihrab influenced by Chinese culture, the rooftops and main buildings influenced by Javanese culture, the tower influenced by European culture. In the ancient time, society had high awareness on different ethnic and believe existed. It is proven by the building acculturation. This value teaches us to appreciate and respect every difference that exists in society, respect to other differences so that it will create peaceful area.

\section{Discipline}

It is actions that demonstrate behavior orderly based on rules, and abide various rules and regulations.

The planting of Sawo trees (Sabu, Madurese language) and Tanjung trees have a philosophical meaning: "Sholat je, bu-ambu (je' ge'pegge') tandhe ajunjung tenggi agama Allah" [4].

In this case, the discipline is shown by the philosophy of two sawo and tanjung trees to the north of the main mosque building which means that workship prayer should not be broken and must be continuously done. There is a lesson to be orderly pray and obey the religion rules.

\section{E. Hard Work}

It is behaviors that show genuine efforts to overcome learning barriers and tasks, and complete tasks as well as possible.

The effort and hard work can be seen in the time taken by Lauw Piango to build the Great Mosque of Sumenep. The Great Mosque of Sumenep was built in 1781 AD $(1200 \mathrm{H})$ and completed in 1785 [4]. It took about five years to complete. Moreover, at that time there was lack of equipment to facilitate the development. It takes hard work, perseverance and persistence in building a magnificent and masterpiece building that has beauty and uniqueness which still stands up to the present.

\section{F. Creative}

It is thought and action to do something in producing new ways or results from something you already have.

It is clear that the architect who built the Great Mosque of Sumenep, Lauw Piango had an amazing idea that united various cultural patterns in one building. So the building not only had a function but also a high aesthetic value. The shape of the building of the Great Mosque of Sumenep was the result of a new piece of thought or creativity, not just adopting or plagiarizing from other forms of building so that none of the buildings had the exact same shape. In other words, the mosque had its own uniqueness that until now this mosque becomes one of the icons of Sumenep Regency.

\section{G. Independent}

It is attitudes and behaviors that are not easy depending on others in completing tasks.

Independent attitude, in this case, does not mean should not interact and absorb the knowledge of foreign nations but more to self-independence to create a distinctive characteristic of the building form which is different from the existing ones. Lauw Piango did not only imitate to produce ordinary building works but more on the development of existing architectural forms that created a new architectural one. The independency of Lauw Piango was proved when he created a mosque that only existed in Sumenep. Without depending on other architectural forms, Lauw Piango actually created innovation 
by combining various architectural styles from various cultures.

This kind of independence action should have become the embryo of our culture so that people do not eliminate national local wisdom and only follow the foreign style in all things.

\section{H. Democratic}

It is way of thinking, behaving and acting that judge the equal rights and obligations among ones and others.

According to Mudra in Kartini, the ornamental variety found in pulpit, maksurah and mihrab is the form of flowering forest plant that symbolizes the diversity of life [1]. There is a diverse population of various ethnicities in Sumenep and accepts the distinction as a unity to maintain peace.

The building also appeared democratic aspects. The mosque indicates that Moslems are not only Arabian or local people but also Moslems who are immigrants from other ethnic groups, such as China. This mosque teaches us that Moslems can come from any different circle, region, and ethnic group.

\section{Curiosity}

It is attitudes and actions that always try to know more deeply and extend information from something he learned, seen and heard.

Lauw Piango's idea in creating an unprecedented new building is the result of a sense of curiosity that is then exposed to a building object. He was so brave to try something new and finally succeeded when trying to make Sumenep at that time became the culmination of civilization in the field of architecture that made Sumenep had its trademark. Encouraging curiosity (in a positive sense) to creative and courageous ideas to try and apply it into invention is remarkable action.

\section{J. Spirit of Nationalism}

It is the way of thinking, acting, and having insight that put the interests of the nation and the country above the interests of self and his group.

The Great Mosque has a big role for the government in that era. Solving and negotiating a problem related to Sumenep regency government was also held at the Great Mosque of Sumenep by Prince Natakusuma I and the courtiers of Sumenep Palace. In the appointment also used the Great Mosque of Sumenep placed in Paseban (auditory) located in the north and south of the Great Mosque of Sumenep [4]. The role of this Great Mosque indicated that although the residents of Sumenep at the time came from various religions, ethnic and culture, Great Mosque of Sumenep as a Moslem worship place used as a place related to discuss governmental issues.

In addition, the spirit of nationality can be seen from the architectural style of the Great Mosque in Sumenep which consists of Chinese, European, Islamic and Javanese cultures. The Kingdom of Sumenep at the time understood with the existence of multi ethnicity in its population, people of that period accepted the distinction as one unity and keep the peace.

\section{$K$. Love the homeland}

It is ways of thinking, acting, and doing that show loyalty, awareness, and high appreciation of the language, the physical, social, cultural, economic, and political environment of the nation.

The motto "Bhinneka Tunggal Ika" used today was worthy pinned in Sumenep at that time, namely before the independence of Indonesia. The arrival of various ethnics which later settled becomes one of the reasons. The building of the Great Mosque in Sumenep proved its existence, the mosque which the art of architecture gets the influence from foreign culture. The architectural form of this mosque represented the diverse population that lived. It described the identity of Sumenep which built on diversity. A sense of pride in the diversity that was applied to a mosque building represented the environment, social, and cultural. Currently, the love of the homeland must be proven by having pride and still preserve national language and culture.

\section{Friendly/Communicative}

It is actions that show the pleasure of talking, getting along, and working with others.

Good communication is reflected by the harmony of local residents who gladly accept newcomers to live, share environments, and live together as members of the community. Communicative and friendly attitude are seen in the acculturation of foreign culture in the building of the Great Mosque. Acculturation in this building showed inter-cultural harmony which shows us the importance of good communication in life.

\section{M.Love Peace}

It is attitude, words, and actions that cause others to feel happy and secure for their presence.

The appeal to keep the brotherhood is in the form of ornaments. Mudra in Kartini argued that the form of two bound spheres symbolizes that fellow Muslims must keep the bonds of brotherhood in order not to be scattered [1].

In fact, the culture of loving peace had been nurtured in the society at that time. Life coexisted between ethnic and beliefs depicted in the shape of the Great Mosque of Sumenep building which adopted from various foreign architectural styles. It teaches us to keep peace and tranquility among other religious fellow.

\section{N. Like to Read}

It is the habit of providing time to read the various readings which gives goodness to readers.

When people like reading, it assumed that they like learning. That attitude needs to be observed from an architect Lauw Piango. Since, it is impossible for someone who had less experienced and less learning was able to build a building in which there was a form of acculturation from various cultures.

In addition, the role of the mosque is used as a means or place to learn and read Al-Quran as well as study Islam. The existence of the mosque familiarize the community to learn and read Al-Qur'an. Thus, learning from one of the roles of the Great Mosque, people should like to read and learn and make them as habit in order to be success. 
It is attitude and behavior of a person to carry out his duties and obligations, which he should do, to oneself, society, environment (nature, social and culture), state and God Almighty.

This attitude is reflected in Lauw Piango, as the architect of the Great Mosque of Sumenep. Lauw Piango had the duty and trust given by Panembahan Somala. Although it needed long process, about five years, Lauw Piango retained the responsibility given to him until the construction of the Great Mosque of Sumenep was completed.

\section{CONCLUSION}

Based on the results of research that has been described above, it can be concluded that character education is now an important thing to be applied in the field of learning, including art and culture lessons. Character education in the arts of culture can be learned from the interpretation of a form of cultural heritage, one of them is the building of the Great Mosque of Sumenep. This research produces the character values contained in the Great Mosque of Sumenep which can then be used as characters teaching materials to students in art and culture lessons. The values of the characters in the Great Mosque of Sumenep include religious values, honesty, tolerance, discipline, hardworking, creative, independent, democratic, curiosity, spirit of nationalism, love the homeland, friendly/communicative, love peace, like to read, and responsibility.

\section{REFERENCES}

[1] F.A. Atthalibi, Semiotics architecture Masjid Jamik Sumenep-Madura. Student Journal of Architecture, 4 (2), 2016.

[2] Kemdikbud, Concepts and guidelines for strengthening character education. Jakarta: Ministry of Education and Culture, 2010.

[3] A. Ronald, Architectural values of traditional house of java. Yogyakarta: Gadjah Mada University Press, 2005.

[4] P.S, Selviana, History of the Masjid Jamik Sumenep the reign of Prince Natakusuma I (Adipati Sumenep XXXI: 1762 -1811 ad). Avatara Journal 3 (1): 440-449, 2013.

[5] Sulasman and S. Gumilar. Cultural theories. Bandung: Pustaka Setia, 2013.

[6] H.A.R. Tilaar, Culture Education and Civil Society of Indonesia. Bandung : PT. Remaja Rosda Karya. 2002.

[7] A. Wibowo, Character education management in school. Yogyakarta: Pustaka Pelajar, 2013.

[8] Z.M. Wiryoprawiro, Madura Sumenep traditional architecture with historical and descriptive approach. Surabaya: Traditional Architecture Laboratory ITS, 1986.

[9] I. Zulkarnain, et al, History of Sumenep. Sumenep: Department of Culture and Tourism of Youth and Sports of Sumenep Regency, 2014.

[10] A. Taylor, Character Education: a Bibliography of Recent Research, Reports and Resources. Slough: NFER, ISBN 978-1-911039-49-5, 2017.

[11] M. Melnyk and J. Bender, Countries and Cultures Around the World, The Ukrainian National Museum and the Ukrainian Institute of Modern Art, 2011.

[12] Blair, Sheila S. and Jonathan M. Bloom. The Art and Architecture of Islam 1250-1800. New Haven: Yale University Press, 1995. 